\title{
Marketing
}

UDC 339.13:504.330:332

doi: 10.12958/1817-3772-2019-4(58)-111-116

Y. Bolotina,

PhD (Philosophical),

ORCID 0000-0001-6939-3840,

O. Shubna,

PhD (Economics),

Y. Nykolaiva,

Donbass State Machine Building Academy, Kramatorsk

\section{USING ENVIRONMENTAL MARKETING TOOLS IN THE IMPLEMENTATION OF THE CONCEPT OF SUSTAINABLE DEVELOPMENT OF THE REGION}

Formulation of the problem. Among the directions of implementation of the strategy of sustainable development of the regions the special place belongs to the concept of eco-marketing. However, the current global and domestic experience of introducing elements of environmental marketing into the processes of managing the socio-economic development of regions is not systematic, since in most studies the focus of environmental marketing focuses on the promotion and promotion of products with environmental characteristics.

However, the concept of eco-marketing is much broader and, on the one hand, encompasses activities for the formation of consumers' environmental needs, production and promotion of eco-products, and on the other - a special case of regional non-commercial marketing, the purpose of which is to create a system of environmental management, environmental protection environment and environmental safety systems [1].

Analysis of recent research and publications. The current state of scientific development of environmental marketing topics does not meet the practical needs of the region in the restoration of ecological systems and the transition to sustainable development. The general theory of marketing, developed in the writings of foreign scientists (G. Armstrong, F. Kotler [1] and others), was created on the experience of countries with developed market economies and not adapted to domestic conditions. Research by domestic authors on environmental marketing is largely an analysis and synthesis of foreign experience, and mainly on the marketing of natural resources. Some studies that are directly or indirectly related to marketing (S. Ilyashenko, O. Prokopenko [2], V. Sabadash [3], M. Malchyk, O. Martynyuk [9] etc.), focused on the analysis of marketing of environmental products, and only approach to environmental issues, remaining within the scope of consideration of the process of formation of environmental needs.

The purpose of the article is to identify possible directions for the development of the region based on the production of environmental goods through the use of environmental marketing tools in implementing the concept of sustainable development of the region.
Outline of the main research material. Among a number of marketing concepts (improvement of production, product concept, concept of intensification of commercial efforts, traditional concept of marketing, concept of social and ethical marketing), the latter, which corresponds to the principles of sustainable development and allows to harmonize the interests of producers (profit), consumers and society at large (sustainable environmental, socio-economic development). The concept of eco-marketing has emerged in its focus, which is to focus production and marketing on meeting ecooriented needs and demands of consumers, creating and stimulating demand for eco-friendly goods (products or services) - cost effective and environmentally safe in production, consumption and utilization. After all, for the formation of voluntary environmental initiatives of the region, enterprises and organizations, the development of the concept of environmentally friendly production, consumption of products and waste management, it is necessary to modify the marketing complex and its tools, taking into account the environmental factor.

The heterogeneity of scientific approaches to the essence of environmental marketing is due to the different attitude of specialists and scientists to this problem. Some define marketing as management, others as the concept, art and philosophy of business or as the market orientation of a company. This diversity of views provides a wide choice of definition for both marketing and environmental marketing. And O.V. Sadchenko, and S.K. Kharichkov views environmental marketing through "the prism of a defined system of concepts, each of which focuses on one of the key factors of environmental marketing". The authors highlight five concepts of environmental marketing [4, p. 56]:

- marketing of goods and services, taking into account environmental standards and restrictions as the most important factor of the environment;

- marketing of environmental goods and services a specific type of marketing caused by the emergence of environmental needs of the population due to the deterioration of the quality of life and increase the environmental awareness of society; 
- marketing of natural resources and resources (marketing of natural resources) - corporate type of environmental marketing, subject to local authorities and national governments - legal managers of natural resources located in the territories of regions and states;

- non-commercial type of environmental marketing aimed at preserving the human habitat and gene pool of the biosphere, as well as taking appropriate measures to reproduce disturbed ecosystems and individual components of the natural environment;

- marketing environmental knowledge and technology - a kind of marketing ideas.

In our opinion, the most successful is the definition, which is based on the integration of marketing approach and environmental requirements of the region, consumers, public, state and international organizations, enterprises. From this point of view, eco-marketing is a management function that organizes and directs the activities of public organizations, state institutions, enterprises, related to the assessment and transformation of consumer requests into environmentally-oriented demand for goods and services that contribute to maintaining quality and quantity. basic ecosystems that satisfy the needs of both individuals and organizations or society at large. In the system of managing the balanced development of the region, a prerequisite is the consideration of the territorial factor in the implementation of the tasks, functions and principles of environmental marketing. On the one hand, the territory from the simple place of economic events becomes the seller of goods and services, that is, an equal participant in the market, and on the other hand, the region (part of the territory) can be sold as an environmental commodity, which has its value and environmental value. The region is regarded as a coherent system and its advertising is exploited by the environmental benefits of the area, such as environmentally friendly sources of drinking water, no air pollution, compliance with environmental standards, etc.

In this case, the environmental marketing of the regions is aimed at attracting investments, development and implementation of environmentally sound programs, projects, regional schemes to prevent the consequences of likely environmental hazards [5, p. 121]. Moreover, the process of evolution of environmental marketing in the region is inextricably linked with the formation of environmentally conscious needs in the market (Figure).

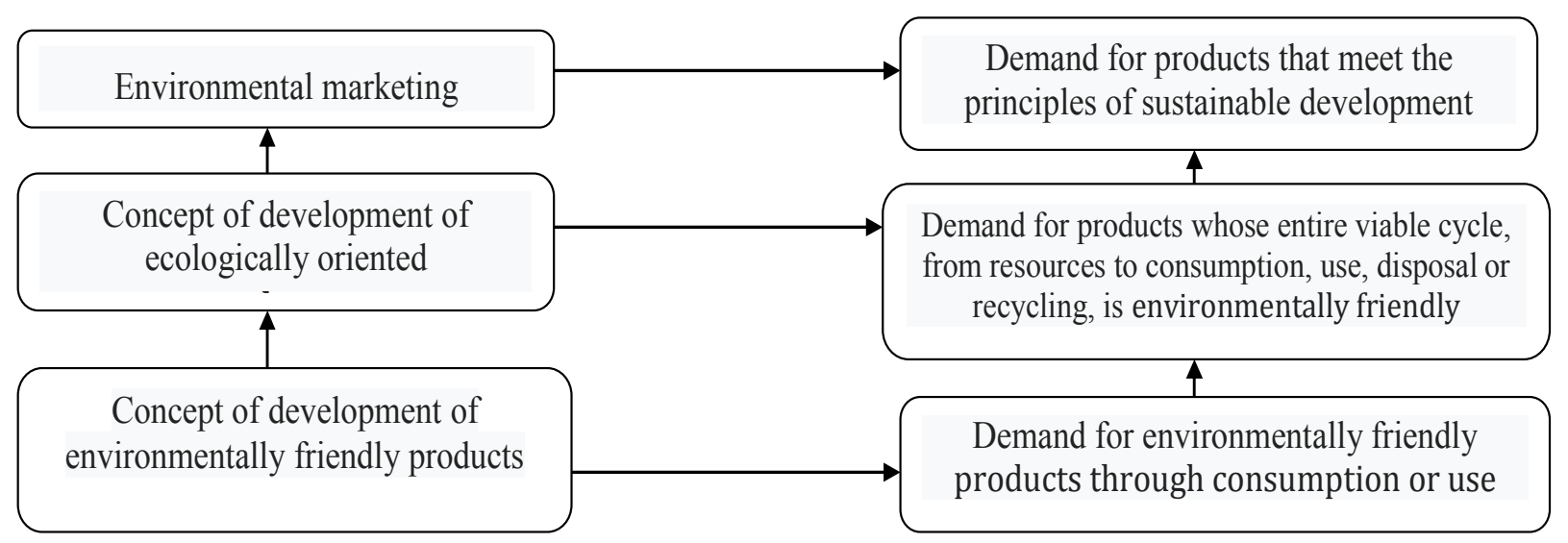

Figure. Developing an environmental marketing concept for the region (based on source [5])

In the existing ecological, socio-economic conditions, the main tasks of environmental marketing of the region include the tasks of formation and development of the market of ecological goods in order to resolve the contradictions between economic development and the need to preserve and further improve the quality of the environment. In addition, environmental marketing tasks include: the formation of environmentally conscious needs in the market; creation of conditions for preservation of environment; adaptation of production to market conditions; development of competitive, environmentally friendly products; intensification of sales of environmentally friendly products; making extra profit through greening production. Enterprises seeking to be competitive and take advantage of environmental marketing have already realized the urgent need for certification through the ISO 14000 series "Environmental Quality Management".

This standard is the most influential standard in the world. Its implementation is an important step towards greening business. The "continuous improvement" concept described in ISO 14001 promotes improvement at all stages of the product or service life cycle. In June 1997, Ukraine approved international environmental management standards (EMS as State Standards of Ukraine (DSTU)). The use of them as voluntary for organizations and enterprises, regardless of their type of activity and form of ownership, was introduced since 1.01.1998. towards customers. The company's products should be designed to ensure environmental safety and sustainable development. It should minimize the use of non-renewable resources and be able to recycle [6]. 
The product environmental tool includes the entire environmental product life cycle, which includes, in addition to production-related steps, all the previous and subsequent stages of the product life:

- market research - first of all - the study of consumer needs and demand for environmental products, taking into account the dynamics of demand, its forecast size, activity in the market competitors, the assessment of existing competitors, consumer behavior, their preferences, attitude to environmental products;

- product design and development - it is at this stage that the environmental characteristics of the products are laid, the environmental impact of the products is assessed throughout the life cycle. At this stage, quality indicators of production are laid. Higher quality goods last longer, refuse to work less frequently, are easier to repair and typically use fewer resources when operating. It is important to emphasize that any environmental properties do not impair the quality and efficiency of the product.

If this does not happen, the consumer must be clearly explained. In terms of quality, products may differ as follows [6]:

1) high quality of usefulness of the products, which is determined by its acceptability for consumption, consumer value, durability, ability to service, appearance and others;

2) high ecological quality of products, which is determined by the production of natural materials, the absence of environmentally harmful substances, and when used, consumed or operated by the absence of residual materials that are harmful to human health and negative impact on the environment;

3 ) high ecological quality of production, which is determined by the level of minimization of the use of materials and energy, replacement of scarce raw materials with raw materials that are in sufficient quantity, replacement of energy sources, reduction of production negative impact on the environment.

By the way, like the traditional ones, the measures of the environmental marketing complex are formed on the basis of situational analysis of market opportunities and threats, as well as the strengths and weaknesses of the enterprise. It is necessary to constantly analyze the internal strengths and weaknesses of the region in terms of environmental marketing: participation and assessment of existing capabilities of enterprises (organizations) in solving regional environmental and economic problems; the level of environmental friendliness of raw materials used in the production of goods by the enterprises of the region; the level of ecodestructive environmental impact of the enterprises of the region (production process, waste, etc.); targeted management installations to address environmental issues; the image of the businesses in the region in terms of consumers and the general public, etc.
The 1994 European Commission report "Economic Growth and the Environment - Some Recommendations for Economic Policy" stated: "In our economy, decisions are made on the basis of price signals. Because consumers make purchasing decisions in line with price changes, and companies determine product design, technological development and production process to a large extent influenced by market prices, it is important that these prices correctly reflect the full costs and benefits for individuals and society..." [7, p. 26].

Considering the environment as a free asset is one of the causes of environmental problems. At the same time, pricing is one of the most effective tools of regulation of environmental safety, a tool that influences consumer behavior and provides a strong incentive for innovation by private enterprises. In some countries of the world (EU countries, Russia) prices for organic goods are high enough and their purchase is not available to most consumers.

In other countries (USA, Canada) production and consumption of environmental goods is more widespread. In addition, in these countries, green production is supported by governments. For the most part, nowadays, most environmental goods are more expensive than conventional goods [8]. Almost everywhere, pricing mechanisms do not reflect environmental costs, so people begin to neglect the environment.

But if environmental and cost-related environmental costs, which include economic losses that occur throughout the product life cycle, are taken into account along with fixed and variable production costs, prices of non-environmental or less environmental goods will become higher. Today, there is every reason to believe that this will soon be the case: if environmental costs were fully taken into account in market pricing, then people were more concerned with the environment. However, on the other hand, it is not easy to get people to pay for what they are used to using for free, especially at low incomes.

However, pricing is one of the most effective tools for eco-efficiency. The price reflects the qualitative composition of the product offer taking into account the environmental components, the level of demand taking into account the environmental disadvantages, needs and opportunities, the state of implementation (exchange) and consumption.

One of the main questions the company has to answer is whether its pricing policy makes it an environmentally friendly choice for its customers. The substantiation, calculation and pricing of environmental products offered by the company include the appropriate procedure and steps (Table 1).

In the classic version, in order to attract consumer interest in products with improved environmental performance and a gradual consolidation in the new market, it is advisable to set reduced prices (or penetration prices) compared to those of competitors or to their own 
prices, which sell the product in already developed markets. After generating demand for eco-friendly products, developing a certain market share and forming a steady clientele, businesses are trying to maximize profits by gradually raising commodity prices to the level of other suppliers' prices.

The mechanism for calculating the price of environmental goods

Table 1 (developed by the author based on source [10])

\begin{tabular}{|l|l|}
\hline \multicolumn{1}{|c|}{ Stages of analysis } & \multicolumn{1}{c|}{ Contents of the stage } \\
\hline Goal setting and goals & $\begin{array}{l}\text { Maximize profit. In Generating demand for environmentally friendly } \\
\text { products and gaining the appropriate share to hold market share }\end{array}$ \\
\hline Demand determination & Upper price limit \\
\hline Calculation of production costs & Lower price limit \\
\hline Analysis of competitors' prices and goods & Prices and products of competitors \\
\hline $\begin{array}{l}\text { Choosing a pricing strategy. } \\
\text { Choosing a pricing method }\end{array}$ & $\begin{array}{l}\text { Based on current prices at a given cost. Average cost + profit. Break- } \\
\text { even at target profit. The current price. Price based on operating effect. } \\
\text { Price based on market demand. Based on the tangible value of the goods } \\
\text { and others }\end{array}$ \\
\hline Setting the final price option & The initial bid price \\
\hline Setting the final price & Final sale price with discounts or surcharges \\
\hline Adjusting the price of the goods & $\begin{array}{l}\text { Adjustment of the price of a product depending on the stage of its life } \\
\text { cycle, degree of competitiveness, environmental safety and useful pro- } \\
\text { perties }\end{array}$ \\
\hline
\end{tabular}

The market is gradually saturated and the main goal of the companies is to retain market share. To this end, firms are taking all possible measures to prevent a decline in sales and aggravation of competition, do not allow excessive overestimation or undervaluation of prices for their products [10]. From the point of view of a completely rational approach to the selection of ecofriendly products, consumers compare the benefit-tocost ratio of the environmental components to the costs of purchasing and using them and favor the products with maximum performance. This comparison can only be made with other products on the market.

Often, even environmental concerns, consumers are reluctant to pay an environmental cost premium. Demand is rising as the price goes up, but the $2 \%$ price margin is below the consumer's awareness, so it is recommended to be bold. Consumers are not indifferent to the environmental factors of commodities willing to pay a higher price for them. The prerequisite of the consumer's desire to pay a price premium for environmental friendliness is to be informed about the environmental friendliness of the goods (first of all, through their marking), without which he will not be able to distinguish them from non-environmental counterparts, and therefore he will not have to pay extra [11].

The environmental marketing communication system is no different from the traditional marketing communication system; by its nature it is always in sight and encompasses a system of information events, persuasion and reminder measures, stimulation, creation of a positive image, which are involved in shaping consumer demand, public opinion and affecting the whole human life, its values and lifestyle. The main elements of com- munication are advertising, sales promotion, public relations and personal selling (Table 2).

Table 2

Marketing communications in the environmental marketing system (developed by source [10])

\begin{tabular}{|l|l|}
\hline $\begin{array}{l}\text { The element of mar- } \\
\text { keting communica- } \\
\text { tions }\end{array}$ & \multicolumn{1}{|c|}{ The goals of the company } \\
\hline Advertising & $\begin{array}{l}\text { Creation of ecologically safe } \\
\text { image of the goods; an image of } \\
\text { a company that cares about } \\
\text { greening its own production and } \\
\text { the environment, reaching out to } \\
\text { potential buyers }\end{array}$ \\
\hline $\begin{array}{l}\text { Demand determina- } \\
\text { tion }\end{array}$ & $\begin{array}{l}\text { Encouragement of purchases, } \\
\text { promotion of the sales network }\end{array}$ \\
\hline Personal sale & $\begin{array}{l}\text { Establishing long-term two-way } \\
\text { communications between pro- } \\
\text { ducer and consumer of environ- } \\
\text { mentally friendly goods }\end{array}$ \\
\hline Public Relations & $\begin{array}{l}\text { Achieving high environmental } \\
\text { reputation of the company }\end{array}$ \\
\hline
\end{tabular}

Advertising is an impersonal form of communication, which is carried out through paid media [9, p. 167] and is one of the most effective tools in the attempts of the enterprise to modify the behavior of buyers, to attract their attention to goods with environmental characteristics, to show the environmental usefulness of goods, to create a positive image of the enterprise itself as environmentally oriented. Advertising serves a variety of purposes, influencing the economy, ideology, culture, 
social climate, education, attitudes toward environmental issues, and other aspects of contemporary reality.

However, its main, traditional purpose - to ensure the sale of goods and profits to the advertiser $[10$, p. $167-$ 168]. The use of environmental brands in advertising is one of the ways of shaping consumer behavior, which would be in line with current economic and environmental realities. The American researchers E. Callenbach, F. Capra and others [11] highlight five aspects that should be emphasized in environmental advertising:

- priority of long-term consumer satisfaction over short-term ones;

- priority of operating costs over initial costs;

- the priority of reliability, durability and safety over the original attractiveness;

- possibility for reuse or recycling of products and its packaging.

In this way, communication activities help to build trust with manufacturers and their products, help to explain the content and importance of eco-labeling, which is an advertising tool and can serve as a guide for consumers when choosing products and increase the competitiveness of goods.

Conclusions. Both external and internal factors should be taken into account in determining possible directions for the development of a region based on the production of environmental goods (services). In turn, the development of the market for ecological products and services is one of the main factors for ensuring the stability of the development of the economy of the region, makes it possible to solve economic, social and environmental problems in the complex.

Thus, addressing environmental problems in domestic regions requires not only a gradual transition from traditional means of establishing environmental constraints, but also active use of environmental management and marketing tools, both at the level of strategic planning for sustainable development of the region and in the economic activity of the enterprises of the region.

The existing lack of experience in applying the concept of environmental marketing can be offset by the use of external consulting, the study of foreign experience and its adaptation to the conditions of the Ukrainian economy, through the development of an environmental education system.

\section{Literature}

1. Основы маркетинга / [Ф. Котлер, Г. Армстронг, Д. Сондерс, В. Вонг]. 2-е европ. изд. СПб.: Издат. Дом «Вильямс», 1998. 1056 с. 2. Ілляшенко С., Прокопенко О. Екологічний маркетинг. Економіка України. 2003. № 12. С. 56-62. 3. Сабадаш В.В. Екологічні конфлікти: теоретико-методологічні аспекти еколого-економічного дослідження. Сталий розвиток та екологічна безпека суспільства в економічних трансформачіях / [Н.М. Андрєєва, В.О. Бараннік, С.В.
Бєлашов та ін.]; за наук. ред. д.е.н., проф. Є.В. Хлобистова. Сімферополь : ПП «Підприємство Фєнікс», 2010. С. 336-357. 4. Садченко Е.В., Харичков С.К. Экологический маркетинг: понятия, теория, практика и перспективы. Одесса, Инст. проблем рынка и эк.экол. исслед. НАН Украины, 2001. 146 с. 5. Садченко О.В. Інтегруюча роль екологічного маркетингу в регіональному відтворенні і сталому розвитку. Регіональна економіка. 2001. №4. С. 123-131. 6. Бородин А. И. Стратегии маркетинга в контексте устойчивого развития. Вестник СевКавГТУ. 2004. №2. С. 47-57. 7. Охрана оружающей среды и экономическое развитие : Потенциал экономических инструментов для улучшения состояния окружающей среды и устойчивого развития в странах с переходной экономикой / Й. Кларер, П. Франсис, Д. МакНиколас, А. Голуб. Сантандре, Венгрия, 1999. 99 с. 8. Овчинникова Н. В. Экологизация потребления как инструмент регулирования внешних эффектов. Вестник СамГУ. 2006. №5/2. С. 27-35. 9. Мальчик М. В., Мартинюк О. В. Сутність і концепція екологічного маркетингу муніципального утворення (міста). Економічний вісник Донбасу. 2017. №1 (47). С. 77-81. 10. Екологічний маркетинг: навч. посібник / А. М. Вічевич, Т. В. Вайданич, І. І. Дідович, А. П. Дідович. Львів : УкрДЛТУ, 2002. 248 с. 11. Прокопенко О. В. Екологізація інноваційної діяльності : мотиваційний підхід: монографія. Суми: Університетська книга, 2008. 392 с.

\section{References}

1. Kotler F., Armstrong G., Saunders D., Wong W. (1998). Fundamentals of marketing. 2nd euro. ed. SPb., Publ. Williams House, 1998. 1056 p. [in Russian].

2. Illiashenko S., Prokopenko O. (2003). Ekolohichnyi marketynh [Environmental marketing]. Ekonomika Ukrainy / Economy of Ukraine, 12, pp. 56-62 [in Ukrainian].

3. Sabadash V.V. (2010). Ekolohichni konflikty: teoretyko-metodolohichni aspekty ekoloho-ekonomichnoho doslidzhennia [Environmental conflicts: theoretical and methodological aspects of ecological and economic research]. Stalyi rozvytok ta ekolohichna bezpeka suspilstva $v$ ekonomichnykh transformatsiiakh / Sustainable development and environmental security of society in economic transformations. Simferopol, PE "Enterprise Phoenix", pp. 336-357 [in Ukrainian].

4. Sadchenko E.V., Kharichkov S.K. (2001). Ecological marketing: concepts, theory, practice and prospects. Odessa, Inst. market problems and eco-friendly. researched NAS of Ukraine [in Russian].

5. Sadchenko O.B. (2001). Intehruiucha rol ekolohichnoho marketynhu v rehionalnomu vidtvorenni i stalomu rozvytku [Integrating the role of environmental marketing in regional reproduction and sustainable development]. Rehionalna ekonomika / Regional economy, 4, pp. 123-131 [in Ukrainian].

6. Borodin A.I. (2004). Strategii marketinga v kontekste ustoychivogo razvitiya [Marketing strategies in the context of sustainable development]. Vestnik 
SevKavGTU / Bulletin of SevKavSTU, 2, pp. 47-57 [in Russian].

7. Clarer J., Francis P., McNicholas D., Golub A. (1999). Weapon protection and economic development: The potential of economic instruments to improve the environment and sustainable development in countries with economies in transition. Santandre, Hungary. 99 p.

8. Ovchinnikova N. V. (2006). Ekologizatsiya potrebleniya kak instrument regulirovaniya vneshnikh effektov [Ecologization of consumption as a tool for regulating external effects]. Vestnik SamGU / Bulletin of SamSU, 5/2, pp. 27-35 [in Russian].

9. Malchyk M. V., Martyniuk O. V. (2017). Sutnist kontseptsiia ekolohichnoho marketynhu munitsypalnoho utvorennia (mista) [Essence and concept of environmental marketing at municipalities (cities)]. Ekonomichnyi visnyk Donbasu / Economic Herald of the Donbas, 1 (47), pp. $77-$ 81 [in Ukrainian].

10. Vichevych A. M., Vaidanych T. V., Didovych I. I., Didovych A. P. (2002). Ekolohichnyi marketynh [Ecomarketing]. Lviv, UkrDLTU. 248 p. [in Ukrainian].

11. Prokopenko O. V. (2008). Ekolohizatsiia innovatsiinoi diialnosti : motyvatsiinyi pidkhid [Ecologization of innovation activity: motivational approach] Sumy, Universytetska knyha [in Ukrainian].

Болотіна Є. В., Шубна О. В., Ніколаєва Ю. В. Використання інструментів екологічного маркетингу в реалізації концепції сталого розвитку регіону

У статті розглянуто розвиток концепції екологічного маркетингу регіону. Визначено, що в існуючих еколого-соціально-економічних умовах до головних завдань екологічного маркетингу регіону відносять завдання формування і розвитку ринку екологічних товарів 3 метою розв'язання суперечностей між економічним розвитком і необхідністю збереження і подальшого поліпшення якості довкілля. Розроблено механізм розрахунку ціни екологічного товару. Визначено, що основними елементами комунікацій в системі екологічного маркетингу є реклама, стимулювання збуту, зв'язки 3 громадськістю та персональний продаж. Комунікаційні заходи допомагають сформувати довірчі відносини до виробників та їх продукції, допомагають пояснити зміст і значення екологічного маркування, яке є рекламним засобом і може слугувати орієнтиром для споживачів при виборі продукції та підвищувати конкурентоспроможність товарів.

Ключові слова: екологічний маркетинг, споживачі, екологічна продукція, ринок, навколишне природне середовище, потенційні покупці.
Bolotina Y., Shubna O., Nykolaiva Y. Using Environmental Marketing Tools in the Implementation of the Concept of Sustainable Development of the Region

The article describes the development of the concept of ecological marketing in the region. It has been determined that in the existing ecological, social and economic conditions, the main tasks of ecological marketing in the region include the tasks of forming and developing the environmental goods market in order to resolve differences between economic development and the need to preserve and further improve environmental quality. A mechanism for calculating the price of environmental goods. It is determined that the main elements of communications in the system of environmental marketing is advertising, sales promotion, public relations and personal selling. Communication activities help build trust with producers and their products, help explain the content and meaning of ecolabeling, which is an advertising medium and can serve as a guide for consumers when choosing products and increasing the competitiveness of products.

Keywords: ecological marketing, consumers, ecological products, market, environment, potential buyers.

Болотина Е. В., Шубная Е. В., Николаева Ю. В. Использование инструментов экологического маркетинга в реализации концепции устойчивого развития региона

В статье рассмотрено развитие концепции экологического маркетинга региона. Определено, что в существующих эколого-социально-экономических условиях к главным задачам экологического маркетинга региона относят задачи формирования и развития рынка экологических товаров с целью решения разногласий между экономическим развитием и необходимостью сохранения и дальнейшего улучшения качества окружающей среды. Разработан механизм расчета цены экологического товара. Определено, что основными элементами коммуникаций в системе экологического маркетинга является реклама, стимулирование сбыта, связи с общественностью и персональная продажа. Коммуникационные мероприятия помогают сформировать доверительные отношения к производителям и их продукции, помогают объяснить содержание и значение экологического маркирования, которое является рекламным средством и может служить ориентиром для потребителей при выборе продукции и повышать конкурентоспособность товаров.

Ключевые слова: экологический маркетинг, потребители, экологическая продукция, рынок, окружающая естественная среда, потенциальные покупатели.

Received by the editors: 24.10.2019

and final form 19.12.2019 